$\begin{aligned} & \text { Lesibana Rafapa } \text { Post-apartheid transnationalism in } \\ & \begin{aligned} \text { Lesibana Rafapa is Associate Professor } \\ \text { and Chair of the Department of } \\ \text { English Studies at the University of } \\ \text { South Africa }\end{aligned} \\ & \text { reality or a fallacy? }\end{aligned}$

Email: rafaplj@unisa.ac.za

\section{Post-apartheid transnationalism in black South African literature: a reality or a fallacy?}

The quest of this paper is to probe whether globalising post-nationalism impacts on post- apartheid black South African English literature in a manner that suggests a blurring of distinctive African identities. This is done against the background that black South African literature right from its written beginnings in the early $19^{\text {th }}$ century has coalesced into a taxonomically distinct entity forming a non-negligible component of South African literature written in English. I first analyse two post-apartheid novels written by the black writers Niq Mhlongo (Dog Eat Dog 2004) and Sindiwe Magona (Beauty's Gift, 2008). Secondly, I consider three post-apartheid novels by the black writers Phaswane Mpe (Welcome to Our Hilllbrow, 2001), Kgebetli Moele (Room 207, 2009) and Kopano Matlwa (Coconut, 2007). I approach an examination of the five post-apartheid novels by separating them into two categories, as a way of indicating that black South African literature of this era remains as stylistically varied as that of earlier periods, albeit broadly within a mould continuing to characterise it as black. In order to justify an underlying common allegiance to localised identity cutting across the two categories in which I place these five post-apartheid novels, evidence of such a pervasively black feature is explained inter-categorically, even as intra-categorical affinities are demonstrated. I trace these two levels of typology within the conceptual framework of two main groups of theorists. The first group consists of commentators such as Carrol Clarkson in her assertion that the identity of black Africans in the post-apartheid era as portrayed in the fiction of writers such as Phaswane Mpe is such that "educated and urbanised individuals should no longer identify" with and share beliefs having to do with African identity and "a common and accountable response to that which the community represents." The attitude of these critics has led to Leon de Kock seeing both black and white post-apartheid literature warranting interpretation with a "sense of a post-national configuration —indeed, now a transnational constellation." I demonstrate in this paper that post-apartheid fiction written by blacks not only defies theorists' subordination of imaginative writers' centrality in social discourse, but goes further specifically to chafe against normative characterisation as transnational. The second main category constituting the theoretical matrix within which I examine the discourses of the five selected novels includes theorists such as Rob Gaylard, in his observation that Es'kia Mphahlele "can be seen as the founder of a tradition of black writing that runs through writers like Miriam Tlali, Mtutuzeli Matshoba, Njabulo Ndebele and Zakes Mda to Phaswane Mpe," with the thread splicing them together being a grounding of these authors' writings in the philosophy or worldview of Afrikan Humanism. Keywords: Black South African English literature, consciousness, identity, post-apartheid, transnationalism.

\section{Introduction}

This paper aims to demonstrate that thus far studies of black South African fiction have been dominated by skewed interpretations that seek to look at it with an 
extraneous cultural lens alienating it from the context in which it is written and to which it is organic. While the analytical perspective this paper negates could ostensibly be passed for some kind of affirmation lending universality and global impact to black South African fiction, the vantage point I adopt in this essay is congruous with the view that a more genuine achievement of such empowerment is a widening of the impact of black South African fiction written in English along with its Africanist anchor. The kind of universality this study wants to assert is one in which the culturally chequered immanence of world cultures pervades the globe as a justly differentiated tapestry in which the broad cluster of African cultures claims its stake.

The objective of this article is a highlighting of concurring smaller stories handled in black South African fiction and larger patterns of collective black thinking framing them, in spite of the globalising public space being a transnational constellation. Transnationalism, according to Leon de Kock (22) entails a "transnational turn [...] [ushering] in a much bigger world" where the desire is "to step beyond the enclosure of the 'national'." My contention is that unfortunate attempts through the ages to reign black South African literature within matrices of dominant discourses of the Centre, coinciding in the post-apartheid era with what the Centre normatively describes as the transnational 'global' public space, have resulted in a homogenisation this paper intends debunking by means of evidence gathered through literary analyses of the selected works. One weakness of the approach this study seeks to dispute stems from what in postcolonial theory is denigrated as the Centre's marginalising representation (Said), as opposed to self-description by the subaltern.

This study focuses on the post-apartheid black novels Beauty's Gift (2008), Coconut (2007), Room 207 (2006), Dog Eat Dog (2004) and Welcome to Our Hillbrow (2001). These novels are shown as taking forward the communal project black South African writers have undertaken since the beginning of this distinct category of South African English literature in written form through the agency of writers such as Ntsikana in the early $19^{\text {th }}$ century (Booi 12; Mphahlele, "Landmarks" 38), its consistent features surviving through the early $20^{\text {th }}$ century as exemplified by the major writer Sol Plaatje (Gray 69) and continuing to be identifiable in the Drum age of the 1950s through to the postapartheid era (Rafapa, "Artistic"; "South African").

Without the group of writers across epochs belonging to what would otherwise be periodic coteries with their attendant menace to free imaginative writing, analytically the literary output of these writers can be put into categories while simultaneously continuing to display generic features of distinctly black South African English fiction.

I demonstrate characteristics of the novels Beauty's Gift and Dog Eat Dog by Niq Mhlongo and Sindiwe Magona respectively, as bearing continuities with those of the segment of black South African writers of the 1950s epitomised by Can Themba. The essay goes on to trace how Phaswane Mpe's Welcome to Our Hillbrow, Kgebetli Moele's 
Room 207 and Kopano Matlwa's Coconut show affinities with the 1950s writings of an aspect of black writing of the time subsuming the narratives of Es'kia Mphahlele.

\section{From Can Themba to Niq Mhlongo and Sindiwe Magona}

There is unacknowledged continuity in respect of black South African writing worth highlighting. For black South African writing, the surface level differing degrees of conformity to post-modernist and post-national liminality continue to show since periods earlier than the post-apartheid era that commenced in 1994 when South Africa attained democratic governance. My perception is that of a complex process of some de-identifying ever-becoming in black post-apartheid novels of writers like Mpe, Mhlongo, Magona, Matlwa and Moele, as opposed to oversimplified views that place this process in a linear progression from national to transnational.

A close look at Niq Mhlongo's 2004 novel Dog Eat Dog reveals intriguing evidence of what may appear as a degree of lightening of black traditional cultural identity. By black traditional cultural identity I mean the kind of group identity that the black residents of post-apartheid Soweto portrayed in Mhlongo's novel are expected to have brought along as they migrated from their rural to urban homes they now live in. Within this paradigm emanating from discourses of English fiction written by black South African writers, rural environments are acknowledged as richer repositories and more capable conservers of traditional culture while urban settlements like Soweto are spaces where the "community's culture has been shaken and disrupted" (Mphahlele, "Fabric of African Culture" 142-43, 147).

Mhlongo's novel exudes a nuanced stance aligning in profound ways to the South African black writing tradition. When the main character Dingz reminisces about the new holiday name for Dingaan's Day in post-apartheid South Africa, there is significantly paradoxical conflict when Dworkin cautions Dingz against calling King Dingaan "the troublesome kaffir king" (214). Dworkin critically blames Dingz's shallow mindedness on "the power of the liberal education," which has "poisoned" the latter's mind and made him "use the language of the exploiters" and call the African king "such a derogatory name" (214). It is within African cosmology where natural order entails being in harmony with the universe consisting among others of the hallowed figure of the traditional leader. According to such spirituality, if the hierarchical order including reverence of traditional leadership were to be thrown off balance, unthinkable damnation befalls human beings.

Indeed Mhlongo does depict the kind of degradation into a dog eat dog existence which blacks are shown to suffer, perhaps as a foretaste of worse to come were they to disown their survival kit embodied in their African identity completely. There is a scene in which, while catching a taxi in a bustling "Jo'burg city centre" where everybody "was trying to make money," Dingz witnesses a young queue marshal 
gratuitously insulting "a male commuter in a blue suit and tie who had mistakenly boarded the wrong taxi", and when an elderly woman tries to tease out of the depraved youths their latent Africanist lifestyle, both the dehumanised male passenger and the culturally deposed elderly figure are insulted (72). The culturally alienating utterances hurled by the queue marshals who have now increased in number in response to the furore include insults to the male passenger like "your mother's cunt," "you shitpot," "stray dog;" and those directed at the elderly woman like "you old prostitute bitch," "fuck me ... you ... randy ... old woman" (72-73).

The taxi queue marshals are "calling loudly in Zulu" and the entire bruising exchange is in the same African language of isiZulu. By this Mhlongo reminds the reader of the characters' belonging to a cluster of African cultures within the context of which human life is held sacred. By this technique, the writer sharply juxtaposes the unAfricanist conduct of the money worshipping queue marshals of desecrating human life by hurling insults at a fellow human being, with a part of the urbanised black population still capable of externalising an Africanist consciousness through expressions that are imbued with such, like "But why insult me like that?" and "Didn't they teach you at your home how to respect your elders?" (72-73). One way in which the profundity of Mhlongo's discourse in this novel is crafted is in his dressing the insulted gentleman in smart western clothes signifying sophistication, and in the interceding old woman's exclamation as she sits in the urbanised mode of transport, invoking the Zulu God Unkulunkulu to bless the lost young men. By enclosing the two characters dramatically in symbols of the Western sensibility their Africanism has adapted to, and merging their mimicry harmoniously with their Africanist personality externalised in their metonymic utterances, the writer elicits the message that characterisation in this novel points to a surviving Africanist sensibility in this culturally hybridised city of Jo'burg. That this is an appropriated cultural trope of the predominantly westernised city of Johannesburg is signified by the writer making clear that this is a version of 'white' Johannesburg known endemically to blacks as Jo'burg.

This kind of discourse is sustained in other parts of the novel, as in the exchange mainly between Dworkin and Dingz. Dwokin's sardonic reference to "the power of liberal education" (214) signifies the potentially totalising power of dominant western culture, for to abandon black traditional regard for traditional leadership is to flit away from black collective identity. That Dingz's Wits University friend Dworkin, a black student himself, chastises Dingz for such a loss of communal identity should point to the survival of such a group cultural consciousness even among black youth after the apartheid era in South Africa. Such is the Africanist discourse of Mhlongo's novel. The veneer of unbalanced hybridity of which characters like Dingz and the taxi queue marshals are an index, need not mislead the reader. The reader should not misinterpret Mhlongo's characterisation of varying qualities of the balance between a resilient Africanist outlook and appropriation of cultural sensibilities of the Centre in 
this post-apartheid novel as asserting a transnationalised black psyche. To do so would be callous and insensitive to an existing black South African writing tradition, according to writers such as Rafapa ("South African") evident earlier in discourses of prose writings by a category of writers including Can Themba. In whatever group of black South African writers even in earlier periods than the post-apartheid era, to what degree depicted black characters seem to have adopted to foreign lifestyles is merely a matter of more or less, as across the pigeonholing black South African writers constitute a continuum of their dialectical negotiation of what Mphahlele (African Image) has described as their "two streams of consciousness."

Dworkin's typical defence of extant group cultural thinking is sustained at this stage, after an earlier discussion ninety-five pages earlier in the plot of the novel when traditional circumcision is discussed, following some mishap at a circumcision school taking place in the township of Langa near Cape Town (119). Significantly, Dingz's friend called Babes mockingly coins the term "Langa suburb," with a tone that dismisses blacks' upholding of tradition after such a migration from rural areas coinciding with the 'post-national' era after apartheid. Pitted against Dworkin's support of continued communal thinking during this era are characters like Themba and Theks, with Dingz this time taking sides with Dworkin to de-stigmatise circumcision within the HIV-AIDS national debate of the time (120). Such vacillation on the part of Dingz regarding group identity within the post-apartheid context of the time is an indication, true to Sarah Nuttall's (94) remarks, that Dingz's flexible thinking make him "a sharp reader of the changing [...] landscape."

For the kind of black post-apartheid youth represented in this novel by Dingz, group traditional thinking is to be handy merely for streetwise survival in the dog eat dog world of 'post-national' Soweto. It is important to recognise here that postnationalism for black South African English literature should refer to a supposed state in which urbanised blacks have softened in their clinging to traditional thinking and practice that formerly defined them as a black nation. When a false death certificate is organised between Dunga and Dingz in order for the dean to be duped to defer exams in Dingz's favour, collective traditional thinking is useful only in order to "complicate everything with tradition" so that "if the dean refused, "the ring of black youth" would accuse him of something to do with race discrimination" (197-98). Dingz, taking advantage of the post-apartheid public space being amenable to this, feigns disappointment at the white Wits dean's "arrogance [...] about black people," threatens to contact the SRC to give the dean "some lessons" about post-apartheid South African populace's "diverse cultures," because as far as Dingz is concerned the rules the dean keeps invoking in denying the former an aegrotat must "take cognisance of the cultural diversity" of the new South Africa (210-11).

The protagonist Dingz is without doubt one of the black South Africans closer to some kind of acculturation amenable to the 'post-national' public space of post- 
apartheid South Africa, in which ideas of cultural diversity that assert blacks' collective cultural identity are on slippery ground. In keeping with the satiric debunking by the writer of a masqueraded cultural identity meant to cheat one's way through, even apparent embracing of culture by the other youths characterised in Dog Eat Dog remains a highlighting more of an underlying collective cultural consciousness among blacks that is threatened in the concrete conditions of the supposedly 'post-national' space portrayed in the novel. Similarly to the generally pessimistic tone of Can Themba's fiction of the 1950s regarding the survival of black traditional ways in the urban environment, Mhlongo's discourse weighs more towards an acknowledgement of the loss of black cultural identity in the post-apartheid public space described by critics such as de Kock as transnational.

This is why Sally-Ann Murray's observation (77) is tenable, that Dingz "is an astute observer who is adept at playing the race card, the traditional card-you name it, it's up his sleeve, anything to secure his precarious life in Jozi on the Wits campus." Dingz's is a much precarious existence anchored not so much in specific collective values as in an ever-becoming survival of the tenuous post-apartheid pubic space. In the sense in which Paola Marrati (211) defines identity formation within a post-national environment, Dingz lives true to the orientation that "any becoming is a movement of de-identification." What matters for Dingz is the concrete and minoritarian in the post-nationalist public space post-apartheid South Africa may be said to be. When Dingz is angered by his own failure to cheat the white Wits official Dr Winterburn, the former takes advantage of the concrete South African public space in which "everyone was trying hard to disown apartheid" $(35,36)$. He thus vents his anger on a poor white lady at the ATM whom he unfairly accuses of being racist, the reason being just that she is white.

In a sense, Dingz and his friends' references to traditional black culture, racism and other group notions within post-apartheid South African public space can be seen as a way in which the de-identifying individual reinforces its ever-becoming state of de-identification by throwing into relief the dividing line self-outside. In keeping with the way Patricia Pisters (185) would put it within the post-colonial paradigm, Dingz's is "a much more clever way" of using "symbolic and allegorical images" for "relating to the outside" rather than align with a resilient black cultural identity.

While some characters of Dog Eat Dog are made to speak in isiZulu as the writer's betrayal of a strong Africanist spirituality, Mhlongo also allows opportunists to use the Zulu language falsely as far as this cultural trait is concerned. Tis is seen when the thugs in Naledi rob Dingz and his friend of money and other belongings and they say "Lethani amawallets wenu la. Give me your wallets" (91), or when on a Soweto train the commuters sing "Tumelo ke thebe. Faith is the shield" (91), and a little later a chorus sings Lerato la Jesu / Le ya maa-katsa / The love of Jesus / It's amaa-zing “(174). Here the 
device strengthens attachment to the here and now. This is as much the straightforward reality of physically being in dog-eat-dog Soweto as is the immanence of citizens reading a copy of the Sowetan newspaper (173).

It is with the same effect that snippets of African language words and phrases are used in Sindiwe Magona's novel Beauty's Gift (2008). When an isiXhosa hymn is sung at Beauty's funeral (12), the effect is to remind the reader that the characters peopling the story are blacks who speak various indigenous languages and not the medium of the novel that is English. Similarly, when Amanda speaks to the deceased at the graveside and refers to her as sithandwa (15), an image of the women's selfempowerment group conversing alternately in English and isiXhosa is conjured up.

We know that Beauty, like most of these women, spoke both English and isiXhosa when Cordelia's playful imagining of Beauty teasing them from the grave evokes the latter by means of the bilingual dialogue "Got you all—Ndinifumene! I just wanted to see how much you all love me. I am most certainly not dead!" When members of the women's group arrive to condole with the deceased friend Beauty's mother Mamkwayi, the elderly woman only speaks to them in isiXhosa (33), a technique used here to remind the reader that she cannot speak English like the younger generation.

Yet the discourse of Beauty's Gift in relation to the way post-apartheid black life is depicted within a globally post-nationalising context is not devoid of marginal pointers to group identity. Reference to Mamkwayi's daughter-in-law as a makoti (31) does hint at an underlying African cultural framework, within which a daughter-in-law runs chores for and tends to the mother-in-law as she would her own mother. Purposeful framing of the action of Beauty's Gift within isiXhosa group cultural identity is even more overt when the writer remarks that the gear of women somehow reminds Amanda that she is "a Xhosa woman-ubhiqile — and married to a Xhosa man-wendile [...] that there was something called tradition" (149). Such indicators of black cultural identity, however, remain marginal and pointing only to a minute degree a feebly resilient traditional psyche.

There is an interesting way in which there are stylistic parallels between Magona and Mhlongo's novels. Extant black cultural thinking externalised by characters in the category of the male commuter and the elderly black woman on the taxi (72-73), however battered, yet manages to wrench the discourse of Dog Eat Dog from propounding a complete transnational consciousness for South African blacks living in the post-apartheid era. Among the youthful characters, Dworkin and the tiny minority thinking like him significantly serve to symbolise a subtly resilient Africanist consciousness despite undoubted attrition represented by the other group of characters, hinting at the novel's identification with a surviving black writing tradition that espouses and hoists high a distinctive African identity, contradicting any normative view of today's black world as totally post- and trans- national. Although both Beauty's Gift and Dog Eat Dog are shaky in their assertion of the existence of 
Africanist thinking in their post-apartheid characters, they remain tied by features outlined above to a black South African literary tradition conflicting with a blanket claim for transnational existence by people of all cultural identities in the postapartheid public space.

\section{From Es'kia Mphahlele to Phaswane Mpe, Kgebetli Moele and Kopano Matlwa}

South African black English writing in the hands of the group of writers sharing their more radical social commentary approach with earlier 1950s writers associated with Es'kia Mphahlele carry forward the taxonomical features of this component of South African literature even in the post-apartheid era. Writers of the 1950s in the typological category of Mphahlele grappled dialectically with earlier guises of transnationalism such as stark colonisation and imperialism. It is these nominally antecedent varieties of a subjugating expansionism that paved the way for what are today theorists' fashionable expressions for the centre's globalising gesture against the subaltern, one aspect of which is an imposition of transnational discourse onto black South African fiction, despite the notion of transnationalism appearing to be alien to this type of South African English fiction.

With this background, it is worthwhile to plumb for signs of resilient ethnic identity in Mpe's postapartheid novel Welcome to Our Hillbrow (2001), in order to demonstrate extant accent in the post-apartheid era on a consistently surviving Africanist consciousness defying dissolution into a transnational public space. In affiliation to the anti- transnationalist tradition of black South African English fiction since the origins of its written forms, the novel contains pointers within its urban milieu to resilient rural richness of ethnic identity. The authorial voice proclaims in the exordium of the novel that "You discovered, on arriving in Hillbrow, that to be drawn away from Tiragalong also went hand-in-hand with a loss of interest in Hillbrow. Because Tiragalong was in Hillbrow. You always took Tiragalong with you in your consciousness whenever you came to Hillbrow or any other place" (48-49).

The rural village of Tiragalong is depicted as an embodiment of surviving African customs and traditions which the black characters of Welcome to Our Hillbrow continue to derive psychic sustenance from even as they embrace Hillbrow lifestyles, because for them Hillbrow has to continue as Tiragalong in order for them to make an Africanist sense of their day to day living in the westernised site of Hillbrow. In this way, Hillbrow is synonymous with urban and metropolitan African living. This is not to say that the urban environment of Hillbrow does not enrichingly mediate the tribal customs of Mpe's characters when they migrate, true to Gluckman's observation in his study of Africans' rural-urban migration that "tribal custom and practice are effective, though much modified by the demands of the urban situation" (76). Such a discourse serves to characterise Mpe as a writer whose literary-discursive contention 
is akin to Mphahlele and other black writers in this category, who are not as relatively more self-descriptively compromising as Niq Mhlongo and Sindiwe Magona.

The main character of Welcome to Our Hillbrow, Refentše, embeds a miniature tragic story echoing that of the novel's main character, through his demonstrated passion for short story writing. The main character of Refentše's fictive world dies of HIV/ AIDS related ailing after what popular gossip judges to be a morally lose life that she embraces upon arriving in Hillbrow. There is the idea of Refentše's character in his short story virtually committing suicide through her abandonment of traditional African morals when she arrives in Hillbrow, reverberating throughout the many layers of storytelling in Welcome to Our Hillbrow. Mpe's stylistic manipulation of language use links the culturally positioned views of suicide to an Africanist eschatology in which suicide is viewed with repulsion (see Mbiti).

The character Refentše himself, in the higher layer story of Welcome to Our Hillbrow, literally commits suicide when he "resolve[s] to tumble down the twentieth floor" of his flat (55). In one more incident, Refentše's former village girlfriend Refilwe goes to study at Oxford, only to return emaciated with full-blown AIDS (118). The motif of suicide is reinforced when Refilwe's illness is judged as "the fruit of sin" (Mpe 112). Mpe ingenuously links the recurring theme of suicide and its Africanist scandalous inflection to a touchstone of idioms and proverbs and their social functioning, thus reinforcing the casting of the plot in an Africanist mould dialectically enmeshing with the post-apartheid public space of Welcome to Our Hillbrow jarringly described as post-national by some critics of South African English fiction. Mpe's prudent handling of the sociolinguistic tools ascends into elegantly potent language, achieving a trademark searing satire against the holier-than-thou African community of Tiragalong who mercilessly make individuals such as Refilwe the scapegoat for absent HIV/AIDS intervention programmes needed to combat the pandemic.

Apart from his effective appropriation of meanings of what would otherwise remain inanely unmarked expressions, Mpe's English text evinces the writer's distinctive handling of the medium of the novel through the use of black ethnic idiom. According to Lustig and Koester, an idiom is "an expression that has a meaning contrary to the usual meaning of the words" (176). The challenge for readers or interpreters of texts using idioms of languages other than the predominant medium the novel purports on the surface to be written in "is to understand the intended meanings of idiomatic expressions and to translate them into the other language" (Lustig and Koester 176). This means that although Mpe's novel is written in English, the ethnic idiomatic expressions in Welcome to Our Hillbrow need to be translated into the "other language" - which this time is paradoxically the very English language in which it is written. The discourse of the novel may not be understood fully if nothing is done about the presence of such culture-specific idioms in its style. Communication is "a symbolic, interpretive, transactional, contextual process in which people create 
shared meanings" (Lustig and Koester 13). This is why the indigenous African idioms in Mpe's novel as well as their cultural context should be interpreted properly so that the text and the reader are able to "'create shared meanings."

When his cousin leaves him alone in a flat the first day he sleeps in Hillbrow, Refentše asks himself "Will they come back?" (9, naa ba tla boa?-my own back translation, here and following). In Northern Sotho idiom, the question naa ba tla boa? (will they come back?) implies that they may die any minute due to the high violence levels in Hillbrow nightlife. Failure to decode the cultural source of this expression may lead to misleading conclusions, including one that Refentše's cousin has an unreliable character and may run away from the newcomer Refentše, perhaps because he sees the village bumpkin as a burden. In traditional rural life where initiation is practiced, the agitated question asked is usually whether the boys going for circumcision "naa ba tla boa?", meaning, "will they return alive?" The idiomatic meaning of the verb boa in this formulaic linguistic construction linked to the cultural practice of initiation is similar to that in the question posed by the agitated character Refentše expressing concern that his cousin may die in the streets of Hillbrow and never return to the flat alive. It is only upon successful interpretation of embedded Northern Sotho idiom that the perceptive reader understands the expression not as an aspersion on Refentše's cousin's temperament. At the more profound level of violent friction between two opposed cultural consciousnesses, the idiom laden expression actually reveals Refentše's fear of culturally alien Hillbrow where, unlike in homely African cosmology, human life is not held sacred and thus one may be murdered at any moment.

A similar danger of under-decoding the discourse of Welcome to Our Hillbrow might arise if the Northern Sotho proverb "a corpse is always de-skinned on someone else's back" (45, letlalo la motho ga le bapolelwe fase is not detected as a proverb). What the proverb says is that generally or usually, no death in traditional African communities is accepted as natural. Specifically in relation to the plot of the novel, the proverb points out that the killing of the old woman on accusations of witchcraft following Tshepo's death by a lightning bolt and his mother's death, apparently through shock on hearing the sad news, is baseless. By the same token, no reader of Welcome to Our Hillbrow will blame Refilwe's unrelenting hope that Refentše will one day return her undying love after they have re-united in Hillbrow, if the Sotho proverb "there was always a return to the ruins; only to the womb was there no return" (82, maropeng go a boelwa; go sa boelwego ke teng) is interpreted fully for what it means. The proverb means that generally, there is no folly in the act of one returning to something from which one earlier sulked, provided that the misunderstanding has been cleared. It is helpful, in this particular instance, that Mpe predicates the proverb with the words "She knew, like all Tiragalong, that ..." (82), thus hinting that the dialogue or opinion is not at all individually attributable to the character Refilwe and does not simply apply specifically to her particular case. 
A communal perspective of the novel is enhanced through such a sustained expression of societal sanction by means of proverbs and other Sotho idiomatic expressions. The effect is that even when dialogue ostensibly proceeds from the mouth of an individual character, it is not individual opinion that is uttered. Clarkson (453) hints at this kind of individually expressed communal dialogue in her observation that "In a traditional African worldview [...] the notion of liability, or responsibility, is intensified to result in an understanding of the self crucially as an agent of cultural continuity."

Many more examples of such a use of African language idiomatic expressions and proverbs pervade Welcome to Our Hillbrow: reference to foreign African nationals as "stretching their legs and spreading like pumpkin plants (26) is sardonically derived from the Northern Sotho proverb monna ke thaka o a naba-that a real African man should not have only one sex partner-when, after accidental sex with the main character Refentše, the woman Bohlale makes the difficult suggestion that the two must confess to the cheated boyfriend and Refentše finds the idea difficult, Mpe uses the Sotho idiomatic expression meaning to lack a suitable solution for a serious problem, "scratching your head gently" (52, ingwaya hlogo); after innocent Piet is accused falsely through the tricks of a quack diviner of casting spells on his cousin Molori and Molori's uncle wants to convince his incredulous nephew that Piet is indeed a wizard, the uncle uses the Northern Sotho proverb "witches have no distinct colour through which other people can recognize and identify them" (moloi ga a na mmala) meaning that Piet's denials do not mean that he is not responsible for sorcery; etc.

Idioms or any cultural forms in more collectivist cultural groups like those of indigenous African cultures represented by characterisation in Welcome to Our Hillbrow, are almost always cited to lend a communal ring to all approaches, opinions and resolutions of individuals and groups in day to day living, while they are mostly averted in similar linguistic events in more individualist societies such as the European in order for credit, in the case of the latter, to reside accordingly in the individual. The fact of Welcome to Our Hillbrow being a novel written in the kind of English permeated with deceptively normative English sentences actually informed by African language idioms and their meanings, warrants caution against factors that handicap successful cross-cultural communication. In their explication of cultural-level dimensions that facilitate or inhibit cross-cultural communication, Gudykunst and Lee (9) observe that "individualism-collectivism is a major dimension of cultural variability used to explain differences and similarities in communication across cultures". A proper reading of Welcome to Our Hillbrow acknowledging Mpe as belonging discursively in the league of black South African writers such as Mphahlele would serve to isolate culturally alien notions of black post-apartheid writing as belonging to the transnational debate, thus facilitating access to the true, distinctive nature of black South African fiction. Optimal decoding of the contents of this distinctive building 
block of South African literature requires what Gudykunst and Lee (9) describe as "communication across cultures". It is important to acknowledge that despite critics such as Michael Chapman (Literatures, "Telling") tending to obscure a resilient communal consciousness in the anteriority of black English writing and those like Clarkson under-decoding it in the early $21^{\text {st }}$ century, gravitation towards such a collective cultural identity continues to characterise black literature in the postapartheid, and perhaps for other South African literatures transnational context of today. Writers like Rafapa ("South African") have argued cogently for an adamantly common identity obtaining in representations of past black South African literature like that of the 1950s, with Gaylard stressing that this taxonomical feature consistently typifies black South African literature obtaining in the Drum decade through to the post-apartheid period.

In Kgebetli Moele's Room 207 (2006), one of the youthful friends attempting to turn the culturally unsettling ambience of urban Hillbrow into a home, named Matome, refers to the adventurous youths' flat as "our locker room away from home" (18). The nostalgic image of the boys' rural home is evident again in the description of a painting of a gallant Masai warrior by one of them named Molamo. After the narrator reveals laudatory identification with the painted African warrior making him "comfortable and at peace" (13), dolefully the narrator protests that collective African consciousness and identity captured in the painting "is coming to its sad end, for globalisation is hungry at their door" (18). Significantly, Molamo finds globalisation repulsive, including the expansionist transnational impulse coming with it.

Extant collective cultural identity is responsible for such a sensibility in Room 207 characters like the painter Molamo and narrator Noko. True to the non-fossilised state of collective black cultural consciousness depicted thus far as underlying to varying intensity fiction hinted at and discussed earlier of writers like Es'kia Mphahlele, Can Themba, Niq Mhlongo and Sindiwe Magona, Moele's Room 207 acknowledges such a consciousness's dynamic counterbalancing of globalisation and other stalwart agents of impertinent cultural identities borne of it, including for some cultures a transnational consciousness. This is why the narrator Noko describes the Venda vendor in Hillbrow apprehensively as someone who "doesn't just sell fruits, you can even get coke if you want it, or pilisi" (165). This is a concession that even someone with an African collective sensibility like the street vendor, pointed to stylistically by his uncompromising greetings to customers strictly in the Venda language (165), cannot be socially insulated from superficial effects of a transnationalising civilisationsymbolised by lifestyle pointers like the selling and consumption of the drug coke (165).

It is for this reason that Noko's words juxtapose conflicting images of both anchored collective and flitting transnationalised outlooks. Examples are "sees his cousin he doesn't want to talk to him, but would rather run from him" (169) and "brother makes 
you his bank in the dirty streets" (169). The kind of cultural framework within which Noko digests Hillbrow life dictates gravitation towards a blood relation like a brother, and a brother has to be valued and cherished for what Africanist consanguinity entails. The transnationally inclined ideas of evading contact with a brother and commodifying blood relationships thus contrasts with the black-nationally identifying traditional notion of filiation, at the most pointing to potential for a possible kind of cultural hybridity. What Murray (86) describes as "the fact of citiness, people moving through time and place" in Room 207 in neither a vanquishing of collective black identities nor some social insularity of post-apartheid blacks from transnationalising influences. Going back to the example of the black vendor combining the nutritious entrepreneurship of selling fruits and vegetables with corrosive drug dealing, it is important to discern the profound message of such a characterisation. Considering the weighty presence of the Africanist consciousness of the black vendor dramatized stylistically through his trademark use of his vernacular in communicating with customers, mentioning of the dark side of his business is not to say that within the transnational or globalising atmosphere of Hillbrow deviant disposition like selling drugs is inherent in other cultures than African clearly responsible for the vendor's corruption. It is the atmosphere resulting from the confluence of African and these other cultures that renders the multicultural society of Hillbrow vulnerable to such aberrant behaviour. It is such an atmosphere Noko and the other characters of Room 207 repel due to the anchor of their collective Africanist sensibility.

One finds a similarly resilient black collective consciousness in the coconut young female protagonist of Matlwa's Coconut (2007), taking advantage of transnationalising or globalising post-apartheid lifestyles to re-invent itself. For Fiks to reminisce that infinity for her means she "would leave this life of blackness and embark on something larger than large and greater than great, something immeasurable and everlasting" (171) is testimony to both the impossibility of her disowning her own collective black identity, and the impossibility of such a black identity discounting the possibility of minor bruising by transnationalising influences around the suburbia she dwells inan environment in which the young woman is ever-becoming. To say that the protagonist of Coconut simply embraces whiteness at the cost of blackness, thereby smoothening up post-nationalism to absolutist descriptions of whiteness and blackness, untenably misses the point made tenably by a writer like Phiri in a 2011 conference presentation, that "Coconut [...] consistently undermines racial absolutism and authenticity." That is why I conclude that in a novel like Coconut, dominant African identities are portrayed alongside a cultural hybridity of black characters across the novels considered in this paper revealed as more profound and pronounced in this specific narrative.

Some writers appear to perceive the incompatibility of the project of black South African writing with normative discursive perspectives including the concept of 
literature being subservient to a transnational outlook dictated to it by theorists and critics inclined towards the Centre. Gaylard and Rafapa ("South African"; Afrikan) have used complementary arguments to show that among the Drum writers of the 1950s, Mphahlele stood out as a more radical advocate of the resilience of collective African cultural consciousness among blacks who faced the globalising effects of urban migration. It is clear from such writers' analyses of the fiction of Drum writers of Mphahlele's calibre that the social tendency of embracing earlier brands of transnationalism contested for space in the psyche of the black cultural groups with a vanquishing adherence to Africanist collective consciousness and identity. Rafapa ("South African") has furthermore remarked that, differently from the group of black South African writers influenced in style and discourse by Drum writers of Mphahlele's school, symbolic language use by black South African writers espousing the project of 1950s writers in Can Themba's category typifies a literature asserting the persistence of collective cultural identities combined with a relatively higher degree of bending to the transnationalising post-apartheid public space.

\section{Conclusion}

Right from its written beginnings in the early $19^{\text {th }}$ century, black South African literature written in English has coalesced into a distinctive stylistic and discursive type. The motive for such a black writing project has been assertion of black nationhood characterised by the resilience of collective cultural identities adapting to, yet surviving, various theoretical contexts. This article has probed the nature of adaptation such a black literature asserting a culturally distinctive national consciousness has forged for itself in today's apartheid public space described for other kinds of South African literature as one championing a transnational discourse. I have conducted my study within a theoretical context where a writer such as de Kock (25) describes the South African public space portrayed in English literature after the 1980s and 1990s as aligned to global trends in which social identity has "transformed from multinational to transnational", because the factors rallying South African writers of fictions around a national cause have eroded.

I approached my examination of transnational influences on black South African literature of the post-apartheid era by first analysing two post-apartheid novels written by the black writers Niq Mhlongo and Sindiwe Magona. I compared their style with that of a group of black South African writers of the 1950s stylistically associated more closely with Can Themba. My findings are that the discourse characterising black South African fiction through the ages obtains in the sub-type represented by these writers. However, Niq Mhlongo's Dog Eat Dog and Sindiwe Magona's Beauty's Gift portray vulnerability towards acculturation accompanying the globalising, transnational post-apartheid public space in a relatively more accommodative manner. 
Scrutiny of three post-apartheid novels in the other category by the black writers Phaswane Mpe, Kgebetli Moele and Kopano Matlwa reveals that the only difference between the two sub-types of black South African fiction is that the last segment of black writers show the impact of global transnationalism on black South African fiction of this era as minimal. In the final analysis, however, the fabric of both kinds of black post-apartheid South African literature is such that it negates views like the one made by Clarkson (454), that the identity of black Africans in this era as portrayed in the fiction of writers such as Phaswane Mpe is such that "educated and urbanised individuals should no longer identify" with and share beliefs having to do with African identity and "a common and accountable response to that which the community represents."

A compounding of South African literature by black and white writers with regard to where it comes from and where it is today is problematic. That this is the case is clear from the way only white writers are enumerated as an index of the South African canonical writing of 1958 to 2004 (see de Kock 21), except for one or two black writers like Bessie Head. A not-so-helpful attempt at acknowledging the presence of black writers on the scene is made by de Kock (22) in his reference to the existence of a transnational/metropolitan influence even in the colonial period. Here modernist white writers like William Plomer and Roy Campbell are given as examples in that past, alongside black writers of the Drum generation who are said to have been influenced by the Harlem Renaissance.

The distinctly contrasting engagements between white and black South African writers with a distinct identity, starting since what critics like de Kock see as past public space imbued with South African nationalism and continuing in the current public space of global post-nationalism, need a more problematised analysis. The otherwise incisive analyses of the literary representations of transition from national to post-national to transnational public spaces by writers such as Clarkson and de Kock call for adoption of a lens proposed in this paper in order for a generic lumping together of disparate building blocks to be averted in discussions of South African fiction written in English. One should be careful not to blur distinctive African identities and nationalism represented in South African literature by blacks, by imposing in a homogenising manner the discourse of transnationalism onto the postapartheid South African public space. If the presence of global post-nationalist everbecoming in post-apartheid black South African literature means the kind of culturally absolutist post-nationalism evoked in literary analyses by writers such as Chapman (Southern, "More") and Clarkson, the existence of such a post-nationalism in the writings is a fallacy.

Marie-Emmanuelle Pommerolle and Johanna Simeant's evaluation of the concept of transnationalism is most appropriate if the literary critical imbalance regarding South African English literature were to be redressed, in their assertion that 
"Transnationalism [...] does not dilute national and cultural identities; rather, it encourages the assertion of identities that can be legitimately claimed as proof of having constituencies" (91). If a different nationalist consciousness and response to transnational forces is depicted as existing in black South African literary characters in exile (see Masemola), how can this convincingly be denied black characters portrayed within the indigenous South African setting? Unless the hitherto transnationalising attitude of hegemonic critics forming opinion on South African literature changes with a realisation that it serves an agenda no less than furthering the marginalisation of subaltern identities, the accuracy of the remark by Pommerole and Simeant will remain inaccessible to them, that "it is possible for newcomers, outsiders, or dominated actors to challenge [...] unequal relationships through the use of symbols and discourses linked to cultural legitimacy and the possibility of building an 'us'" (91).

Works Cited

Booi, Vuyani. " Ntsikana." African Intellectuals in 19th and Early $20^{\text {th }}$ Century South Africa. Ed. Mcebisi Ndletyana. Cape Town: HSRC Press, 2008. 7-16.

Chapman, Michael. "More than Telling a Story: Drum and its Significance in Black South African Writing." The Drum Decade. Stories from the 1950s. Ed. Michael Chapman. Pietermaritzburg: U of Natal P, 2001. 183-238.

- Southern African Literatures. London: Longman, 1996.

Clarkson, Carrol. "Locating Identity in Phaswane Mpe's Welcome to Our Hillbrow." Third World Quarterly 26.3 (2005): 451-59.

De Kock, Leon. "The End of 'South African' Literary History? Judging 'National' Fiction in a Transnational Era." SA Lit Beyond 2000. Ed. Michael Chapman and Margaret Lenta. Pietermaritzburg: U of KwaZulu-Natal P, 2011. 19-49.

Gaylard, Rob. "Welcome to the World of Our Humanity: (African) Humanism, Ubuntu and Black South African Writing." Journal of Literary Studies 20. 3 \& 4 (2004): 265-82.

Gluckman, M. "Anthropological problems arising from the African industrial revolution." Social Change in Modern Africa. Ed. A. Southall. London, New York, Toronto: OUP, 1963. 67-82.

Gray, Stephen. "Redefining the Canon: The Case for Douglas Blackburn, Stephen Black and Sol T. Plaatje." Ed. Michael Chapman, Colin Gardner and Es'kia Mphahlele. Perspectives on South African English Literature. Johannesburg: Ad Donker, 1992. 60-74.

Gudykunst, William B. and Carmen M. Lee. "Cross-Cultural Communication Theories." Cross-cultural and intercultural Communication. Ed. William B. Gudykunst. London, New Delhi: Sage Publications, 2003. 7-34.

Lustig, Myron W. and Jolene Koester. Intercultural Competence. Interpersonal Communication across Cultures. Boston, etc: Allyn \& Bacon, 2010.

Magona, Sindiwe. Beauty's Gift. Cape Town: Kwela Books, 2008.

Marrati, Paola. "Against the Doxa: Politics of Immanence and Becoming-Minoritarian." Micropolitics of Media Culture: Reading the Rhizomes of Deleuze and Guattari. Ed. Patricia Pisters. Amsterdam: Amsterdam UP, 2001. 205-20.

Masemola, Kgomotso Michael. "Between Tinseltown and Sophiatown: The Double Temporality of Popular Culture." Journal of Literary Studies 27.1 (2011): 1-27.

Matlwa, Kopano. Coconut. Johannesburg: Jacana, 2007.

Mbiti, John. Bible and Theology in African Christianity. Nairobi: OUP, 1987.

Mhlongo, Niq. Dog Eat Dog. Cape Town: Kwela Books, 2004.

Mphahlele, Es'kia. “The Fabric of African Culture and Religious Beliefs." Es'kia. Ed. J. Ogude, S. Raditlhalo, N. Ramakuela, M. Ramogale, P. N. Thuynsma, P. N. (Cape Town: Kwela Books, 2002. 142-56. 
Mphahlele, Es'kia. "Landmarks of Literary History: A Black Perspective." Perspectives on South African English Literature. Ed. Michael Chapman, Colin Gardner and Es'kia Mphahlele. Johannesburg: Ad Donker, 1992. 37-59.

- The African Image. London: Faber and Farber, 1974.

Murray, Sally-Ann. "On the Street with Vladislavic, Mhlongo, Moele and Others." SA Lit Beyond 2000. Ed. Michael Chapman and Margaret Lenta. Pietermaritzburg: U of KwaZulu-Natal P, 2011. 69-96.

Phiri, Aretha. "Coconut and the Dialectics of Race: Interrogating Images of Whiteness and Blackness in (Black) Literary and Cultural Studies." 10 Nov. 2012. <www.ed.ac.uk/school-departments/>

Pisters, Patricia. "The Mosaid Film: Nomadic Style and Politics in Transnational Media Culture." Thamyris/Intersecting 23 (2011): 175-90.

Pommerolle, Marie-Emmanuelle and Simeant, Johanna. "African voices and activists at the WSF in Nairobi: The uncertain ways of transnational African activism." American Sociological Association XVI.1 (2010): 82-93.

Nuttall, Sarah. Entanglements: Literary and Cultural Reflection on Post-apartheid. Johannesburg: Wits UP, 2009.

Rafapa, Lesibana. "Artistic innovation through cultural symbols: A strategy for sustainable development in Kgebetli Moele's Room 207." Africa and Beyond: Arts and Development. Ed. P. Ebewo, I. Stevens and M. Sirayi. Newcastle upon Tyne: Cambridge Scholars Publishing, 2013. 439-51.

Rafapa, L .J. "South African Drum writers of fiction: The English Language and African Identity." English Language and Literature: Cross Cultural Currents. Ed. M. M. Bagwasi, M. M. Alimi and Patrick Ebewo. Newcastle upon Tyne: Cambridge Scholars Publishing, 2008. 254-62.

Rafapa, L. J. and Mahori, Freddy. "Exorcising the ghost of the past: The abandonment of obsession with apartheid in Mpe's Welcome to Our Hillbrow." Tydskrif vir Letterkunde 48.2 (2011): 155-70.

Said, Edward. "Abecedarium Culturae: Absence, Writing, Statement, Discourse, Archaeology, Structuralism." Beginnings: Intention and Method. New York: Columbia UP, 1975. 277-344. 